Teaching and Learning, Vol 4, No. 3, 2008

\title{
Examining New Aboriginal Teachers' Experiences: Understanding Realities and Building Relationships
}

\author{
Lorenzo Cherubini: Brock University, Canada \\ Julian Kitchen: Brock University, Canada
}

\begin{abstract}
The realities of Aboriginal education in Ontario are complex and multi-faceted. After many years of advocacy by Aboriginal leaders, governments and educational authorities are becoming more receptive to Aboriginal education concerns. At the same time, over $42 \%$ of 15 to 29 year-olds in Ontario left school with less than a high school education (Aboriginal Peoples Survey, 2001). Even more concerning is evidence that the health of Aboriginal culture continues to decline. A recent Statistics Canada report states that "the proportion of North American Indian children with an Aboriginal mother tongue fell from 9\% in 1996 to 7\% in 2001" (Aboriginal Peoples Survey, 2001). Aboriginal teachers have a critical role to play in the improvement of Aboriginal education and, particularly, in the preservation and renewal of Aboriginal languages and cultures. Although there is strong evidence that the minority students have higher academic, personal, and social performance when taught by members of their own ethnic group and with culturally responsive approaches (National Collaborative on Diversity in the Teaching Force, 2004), there is little research on the needs of Aboriginal educators. The literature is particularly silent about new Aboriginal teachers' successes, problems, and the impact of their teacher education programs on their practice. These challenges, particularly the critical need for Aboriginal teachers able to support student learning and contribute to the preservation of their distinct languages and cultures, prompted us to conduct research with new Aboriginal educators.

Better understanding of the challenges faced by teachers, particularly new Aboriginal teachers can also help Canadian Aboriginal communities and other governmental organizations with responsibilities for the education of Aboriginal children develop policies that address the needs of Aboriginal educators and students. In particular, research with new teachers can contribute to the development of policies and programs that improve Aboriginal teacher retention and increase the effectiveness of qualified Aboriginal teachers. This, in turn, has the potential to contribute the preservation and renewal of Aboriginal languages and cultural traditions in future generations.
\end{abstract}

\section{Objectives}

The objectives of this developmental research study are:

(a) To examine new Aboriginal teachers' perspectives on the effectiveness of their teacher education programs in terms of preparing them for their roles as teachers, particularly in relation to Aboriginal languages, cultures, and epistemologies.

(b) To examine the perceptions and experiences of new Aboriginal elementary school teachers in terms of the level of support they anticipated receiving during their induction into teaching; their observations about school organizational culture; and their expectations of being a teacher.

(c) To investigate the type, frequency, and perceived value of school and district support in terms of Aboriginal language instruction. 
(d) To examine and apply research methodologies that are compatible with Aboriginal epistemologies and traditions.

(e) To evaluate the Wildfire Gathering (WG) as a research methodology and as an approach to new Aboriginal teacher development.

In this report on an ongoing research project, we outline our research methods and identify themes that have emerged from a preliminary analysis of data collected at retreat with six new Aboriginal teachers. The findings of this project will form the basis for a more comprehensive research investigation that will contribute to the Aboriginal teacher support discourse on a nation-wide level.

\section{Research Method}

In this research, we are particularly interested in listening to the voices of new Aboriginal teachers across Ontario. Equally important is ensuring that Aboriginal participants see their cultural norms embedded and respected in a research study.

Recognizing that the distinctive circumstances facing new Aboriginal teachers could not be investigated meaningfully through surveys or interviews, we brought together six participants for a formal group field interview (Fontana \& Frey, 2000) in the form of a three-day Wildfire Gathering at a retreat centre. Wildfire Research Method (Hodson, 2004) is designed to complement traditional and cultural beliefs, as well as Aboriginal methodologies and knowledge paradigms (Battiste, 2002; Cajete, 2000; Kawagley, 1995; Womack, 1999) by engaging participants and researchers in authentic conversations in an environment that was respectful of Aboriginal languages and cultures. An Aboriginal facilitator led the session, while an Aboriginal Elder played an important role in fostering a communal and sacred environment in which participants could speak safely of their professional identities, experiences and contexts. As Cajete (2008) observed, "Indigenous educational research is best performed when an Indigenous view and purpose are represented in the conceptualization, development, and implementation of research" (p. 204).

In coding and analyzing transcripts from the sessions, we were attentive to Aboriginal worldviews found in collectivity and connection (Smith, 1999). Mainstream researchers worked alongside a Native Elder and Aboriginal staff of the Tecumseh Centre for Aboriginal Research and Education at Brock University. Working collectives and, times in small groups, this tenperson bi-epistemic collaborative team coded and analyzed 130 pages of transcripts. In the process, the Aboriginal researchers offered culturally-sensitive understandings of the text that would have eluded us as researchers not immersed in their traditions and culture. Members of the collaborative team will also be involved at all stages of analysis and writing, including the dissemination of findings at conferences and in journals.

\section{Participants' Voices}

In the Wildfire Gathering, the participants spoke candidly from their experiences as Aboriginal teachers. In this section, we examine four significant themes that emerged from these discussions: (1) the need for more culturally appropriate teacher education; (2) the lack of adequate teacher induction support; (3) the challenges of teaching native languages where language and culture have been eroded due to the impact of colonization; and (4) the dedication and commitment of beginning teachers.

\section{Teacher Education}

The six participants had a wide-range of teacher education experiences. 
Two received their preparation in mainstream university degree programs. These two, who also lived in families that were comfortable working within the mainstream society, seemed to adjust normally to their educational programs. They were particularly well-prepared as teachers, even though they're programs did not focus on Aboriginal teaching and learning; one teaches in a mainstream setting while the other teaches on a reserve. Although they were educated in mainstream programs, both made efforts to incorporate Aboriginal ways of knowing into their teaching.

Three participants were educated in Native Teacher Education Programs (NTEP), short duration certificate programs for prospective Aboriginal teachers. Our participants credited these programs with providing them with basic skills in areas such as lesson planning and classroom management. They did not, however, regard these programs as culturally-sensitive. While some students loved the program's mainstream orientation, one participant reported, it was very difficult for students who grew up within communities steeped in Aboriginal culture. Few educational accommodations were made in response to the diversity of interests, skills and needs of the group. This participant also complained that "they took away that creativity which is ingrained in us and said we don't want it here." The limited scope for cultural knowledge and creativity, he reported, led some of the most promising students to leave the program. The other two NTEP trained teachers also criticized their programs as neither Aboriginal nor supportive of cultural ways of learning and teaching.

The final participant had no formal credentials, but drew on a wealth of life experiences, some of which involve teaching or counselling in adult settings. This self-taught teacher was passionate about his language and worked hard every night inventing language resources for his students. The other teachers also seemed to rely more on their life experiences than their educational experiences in attempting to develop curriculum and instruction.that reflected indigenous culture.

\section{Teacher Induction}

While the induction years are often challenging for beginning teachers, they are particularly so for Aboriginal educators.

One challenge is the lack of curricular support, whether in public schools or reserves. One beginning Native language teacher in a public school stated, "I didn't have any paperwork [curriculum resources] - nothing. Also, the available materials were generally not consistent with the expectations in provincial guidelines." The impact of limited curriculum materials was compounded by the "overwhelming" challenges of teaching Aboriginal language classes of more than thirty students. Also, they often had to work with large numbers of students with special needs, often with inadequate support from educational assistants. One participant lamented, "There's just way too many students who are special needs."

Whereas teacher induction programs are providing new mainstream teachers with orientation sessions, professional development and mentoring, our participants shared stories of isolation. One participant recalled that "the only one that would greet me in the morning and say hi was the custodian....I would walk into the staff room [and] everybody would go quiet," while another was unable to obtain a proper desk for her papers. One new teacher described being treated "like you're not a real teacher." This prompted another to complain that "there is no training on how to work with [mainstream] colleagues." Some also experienced covert and overt racism, which suggests that mainstream colleagues may need training in working with Aboriginal educators. 
The collective resolve of these new Aboriginal teachers was effectively summarized by one participant who stressed the importance of "building our own curriculum. Waiting for somebody else to come along or waiting for somebody else to make it may never happen."

\section{Teaching Native Languages}

Teaching Native languages, which is crucial to the preservation of culture, was a particular challenge for many new Aboriginal teachers. A lack of curriculum materials meant that participants often had to develop their own resources, even though they had received little preparation in unit planning. Classroom periods as short as twenty minutes in length encouraged conventional approaches to teaching that decontextualized language from tradition and culture. This is particularly problematic as participants regard learning language and culture as a holistic and lifelong process for the betterment of their community (as discussed in Canadian Council on Learning, 2007). Another institutional constraint was the lack of full-time teaching positions for Aboriginal language teachers, who often must make considerable financial sacrifices in order to accept part-time positions.

While some Aboriginal students were receptive to language learning, especially with dedicated teachers, apathy or resistance were common. One teacher reflected, "They've got that attitude: What do I need it for? I'm never going to use it. And that's because the parents don't appreciate it." She then recounted how a whole generation, the parents of her students, lost their traditional languages in the wake of the harm done by residential schools. This reality means that many teachers, rather attempting to preserve language, are responsible for language reclamation in communities in which the parents are not language-speakers. This led one participant to question the validity of "the curriculum if those students aren't retaining any of the language they're learning." As another participant concluded, "If they're not learning, they're not living the language."

Shortly after participants identified these significant challenges, however, the conversation shifted to the joy of teaching and discussion of effective strategies for Aboriginal language teaching. This included discussions about alternatives to conventional literacy practices and ways of incorporating culture into the curriculum

\section{Teacher Commitment}

The participants' resolve in the face of these challenges brings to light the resurgence of Aboriginal self-determination whereby new pedagogies and methodologies are being developed to decolonize their students and schools (Grande, 2004; Lomawaima \& McCarty, 2006; Smith, 1999).

This is evident in the participants' awareness of the challenges facing them as Aboriginal teachers. They demonstrated deep commitment to sustaining Aboriginal epistemologies and encouraging culturally-appropriate learning for their Aboriginal students. Participants were highly sensitive to the importance of developing self-esteem so that Aboriginal students are more likely to succeed in school. One teacher with a "passion for the language" sought to be "that role model and that connection that the students had to make [to] feel more at home at school."

While the Aboriginal teachers in this study focussed primarily on their own teaching and the particular contexts in which they worked, all of them articulated critical awarenss of asymmetrical power relations among cultures (Giroux, 1992; Freire, 1985) that were challenging for both them and their students. One teacher sought to "educate the non-Native educators to see that our culture is equal and valuable... and not try to equate or compare our culture and values with their white values." Typical of other comments, another individual stated, "I feel that 
somebody has got to be there believing in the kids, believing in their ability to be there [school], to be proud, to be hard-working... we owe it to our s who have fought so hard."

\section{Final Thoughts}

There is a pressing need to prepare and support Aboriginal educators to teach Aboriginal students and in doing so to preserve their cultural and linguistic traditions (Neegan, 2005).

The alarming levels of educational achievement among Aboriginal Canadians highlight how challenging their work is, and how critical education is to perpetuating Aboriginal language and culture, and preparing students for life success. More than 12\% of Aboriginal Canadians between the ages of 15-29 drop out before Grade 9 (versus 1.9\% of non-Aboriginal); almost $50 \%$ between the ages of 18 and 24 lack a secondary school diploma (versus $20 \%$ of nonAboriginal); and $37.5 \%$ of 15-24-year-olds are neither in formal schooling nor employed in the workforce (Robertson, 2003).

The stories shared by our participants suggest that, while they are deeply committed to Aboriginal education, they are often working with little support. Teacher education programs for Aboriginal teachers in Ontario need to be thoroughly reviewed to ensure that they serve the needs of Aboriginal communities, and prepare teachers ready to teach in a culturally-appropriate manner. Some programs are so rigorous (or rigid) that a majority of Aboriginal teacher candidates, particularly those with deep roots in their culture, withdraw before graduation. Graduates, while prepared for the procedural aspects of schooling, sometimes feel ill-prepared to the unique needs of their students or to teach through language or culture. Many lack support once they arrive in schools, while others perceive that they are deliberately marginalized by colleagues. Since teachers, along with parents, have a profound influence on students' dispositions to education (Brittan \& Maynard, 1985), it is critical that Aboriginal teachers be better positioned for success. Otherwise, many talented and dedicated teachers may give up or become 'burned-out' as a result of their efforts.

The discussions during the Wildfire Gathering suggest that there is a generation of Aboriginal educators who have the capacity to make a difference for Aboriginal student learning and the preservation of Aboriginal languages and culture. These teachers, however, are more likely to be successful if their efforts are supported by education system and the communities in which they work. Our research into their experiences within their communities aims to contribute to the understanding of the community they serve and, particularly, how Aboriginal teachers can best be supported as they work to renew their languages and cultures through education.

This research is supported by a 2-year Social Science and Humanities Research Council (SSHRC) grant from the Canadian federal government. 


\section{References}

Battiste, M. (2002). Indigenous knowledge and pedagogy in First Nations education: A literature review with recommendations. Prepared for the National Working Group on Education. Ottawa, ON., 1-69.

Brittan, A., \& Maynard, M. (1985). Sexism, racism and oppression in education. Oxford: Basil Blackwell.

Cajete, G. (2008). Sites of strength in Indigenous research. In M. Villegas, S.R. Neugebauer, \& K.R. Venegas (Eds.), Indigenous Knowledge and education (pp. 204-207). Cambridge, MA: Harvard Educational Review.

Canadian Council on Learning. (2007). Redefining how success is measured in First Nations, Inuit and Métis Learning. Report on Learning in Canada. Ottawa, ON: Author.

Fontana, A. \& Frey, J.H. (2000). The interview: From structured questions to negotiated texts (pp. 645-672). In N.K. Denzin and Y.S. Lincoln (Eds.), Handbook of qualitative research, $2^{\text {nd }}$ Edition. Thousand Oaks, CA: Sage.

Freire, P. (1985). The politics of education: Culture, power and liberation. South Hadley, MA: Bergin \& Garvey.

Giroux, H. (1992). Border crossing: Cultural workers and the politics of education. New York: Routledge.

Grande, S. (2004). Red Pedagogy. New York: Rowman \& Littlefield.

Hodson, J. (2004). Learning and healing: A wellness pedagogy for Aboriginal teacher education. Unpublished master's thesis, Brock University, St. Catharines, Ontario, Canada.

Kawagley, J. (1995). A Yupik worldview: A Pathway to ecology and spirit. Prospect Heights, IL: Waveland Press.

Lomawaima, K.T., \& McCarty, T.L. (2006). To remain an Indian: Lessons in democracy from a century of native American education. New York: Teachers College Press.

National Collaboratie on Diversity in the Teaching Force (2004). Assessment of diversity in America's teaching force: A call to action. Washington, D.C. National Education Association.

Neegan, E. (2005). Excuse me? Who are the first peoples of Canada? A historical analysis of Aboriginal education in Canada then and now. International Journal of Inclusive Education, 9(1), 3-15.

Robertson, H. J. (2003). Decolonizing schools. Phi Delta Kappan, 552-553.

Smith, L.T. (1999). Decolonizing methodologies: Research and Indigenous peoples. London: Zed Books.

Womack, C.S. (1999). sesMinneapolis: University of Minnesota Press. 